BLS 33, No 2 2007. DOI: http://dx.doi.org/10.3765/bls.v33i2.3505

(published by the Berkeley Linguistics Society and the Linguistic Society of America)

\title{
Split Coordination in Otomi
}

\author{
ENRIQUE L. PALANCAR \\ Universidad Autónoma de Querétaro
}

\section{Introduction ${ }^{1}$}

In this paper, I describe a special coordinating construction in San Ildefonso Tultepec (SI) Otomi, a Mesoamerican language from the Otomanguean stock spoken in Central Mexico. An instance of this construction is given in (1): ${ }^{2}$

$$
\begin{aligned}
& {[\text { nǒ }=\mathrm{r} \quad \text { Xúwa }]_{\mathrm{NP} 1} \quad \varnothing=\text { ñúng }=\text { wí }[=\mathrm{r} \quad \text { Pédro }]_{\mathrm{NP} 2}} \\
& \text { DEF.SG }=\text { SG John 3.PRS=have.a.meal. } S=\mathrm{DU}=\mathrm{SG} \text { Peter } \\
& \text { 'John is eating with Peter'. (lit. 'John has a meal Peter'.) }
\end{aligned}
$$

Here we have two actor participants, John and Peter, which are grammatically encoded in two separate NPs in the clause. The NP encoding John is topical and is placed before the verb while the one encoding Peter occurs after the verb and is not topical. The verb agrees with a dual subject by means of the enclitic $=w i$, suggesting that at some underlying level these two NPs form a conjoined structure similar to the surface structure of English in example (2):

\section{(2)}

\section{John and Peter had a meal}

\footnotetext{
1 I want to thank the following people for helping me understand this complex phenomenon: Alejandra Capistrán; Alexandra Aikhenvald; Guilles Polian; Judith Aissen; Michael Knapp; Pamela Munro; Roberto Zavala; Thomas Smith; Valentín Peralta; Verónica Vázquez; and especially to Paulette Levy who also gave me clues about how to approach it. I am also grateful to Dan Stauffer for proof-reading the text.

2 In the orthographic representation of Otomi, the deviations from the IPA are the following: ' $/ ? / ; f / \mathrm{p}^{\mathrm{h}} / ; j / \mathrm{k}^{\mathrm{h}} / ; y / \mathrm{j} / ; x / \Sigma / ; t x / \mathrm{t} \square \Sigma / ; \tilde{n} / / / ; r / \mathrm{P} / ; \tilde{r} / \mathrm{r} / ; a / \mathrm{a} / ; \underline{a} / \square / ; \underline{e} / \mathrm{E} / ; \underline{o} / \square / ; \underline{u} / / /$.

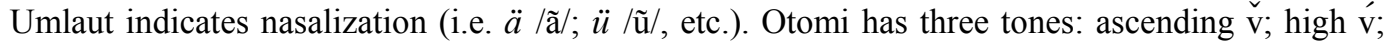
and low (not represented). Abbreviations: = clitic; $<>$ non-concatenative morpheme; . absence of morpheme boundary; B bound form; DAT dative; DEF definite; DEM demonstrative; DU dual; EX exclusive; F free form; IMP impersonal; IN inclusive; IND indefinite; IRR irrealis; LOC locative; $\mathrm{M}$ middle voice; NEG negative; NPS non-present stem; OBJ object; OBV obviative; P particle; PL plural; POSS possessive; PRG progressive; PRS present; PST past; PURP purposive; QUOT quotative; REC reciprocal; REL relative; $S$ suffixal form; SEQ sequential; SG singular; TAM tense/aspect/mood.
} 
Nevertheless, given that the conjuncts involved in the Otomi example in (1) appear in different positions in the clause, I call this coordinating construction the "Split Coordination Construction" (SCC), (following Bruening 2004).

The SCC is used in Otomi to express a comitative event. The semantic role of Peter in the Otomi example is similar to the one played by Peter in (3) in English:

\section{John had a meal with Peter}

In a comitative event, two or more actors are portrayed as performing an action simultaneously, but they receive a different grammatical encoding, which reflects an asymmetry in conceptual and discourse prominence. In this asymmetry, the comitative participant is the least prominent actor, while the most prominent one is commonly topical. As in Stolz (2001), I call this prominent actor the "focal participant", while the comitative is called the "associate participant".

In my analysis of the Otomi structure in (1), I take the role of Peter in the second NP as a prototypical comitative for three reasons: (a) it is a less prominent actor than John; (b) by virtue of the structural split, this NP is encoded in a different fashion than the NP expressing John; and (3) the structure has semantic implicatures of simultaneity typical of comitative structures; that is, in both (1) and (3), John and Peter have a meal at the same time, in the same place, and together, whereas these implicatures are not necessarily present in (2).

Apart from expressing a typical comitative event, the SCC is also used to express asymmetrical reciprocal events, as shown in (4):

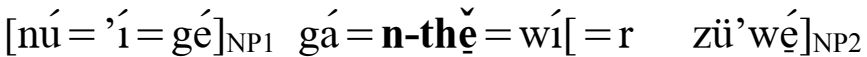

$$
\begin{aligned}
& \text { DEF.SG }=2=2 S G \quad 2 . P S T=M-m e e t=D U=S G \text { worm } / \text { devil }
\end{aligned}
$$

'You came across the devil'.(lit. 'You met with the devil'.) (Moneda: 120)

SCCs of the type illustrated in (1) and (4) occur cross-linguistically. A similar construction is found in Passamaquoddy (Bruening 2004), shown in (5a). It is also found in verb coded coordination constructions when one of the conjuncts is placed in a preverbal topical position, for example in (6a) in Hausa:

(5) Passamaquoddy (Algonquian), (Bruening 2004:2)

Split Coord. a. [Piyel] ali-wiciyew-t-uwok Piyel around-go.with-REC-3PL Mary-OBV 'Piyel and Mary are going around with each other.'

Normal Coord. b. [Piyel naka Mali] ali-wiciyew-t-uwok Piyel and Mary around-go.with-REC-3PL 'Piyel and Mary are going around with each other.' 


\section{Split Coordination in Otomi}

(6) Hausa (Afro-Asiatic, Chadic), (Abdoulaye 2004)

Split Coord. a. [Feemi] [sun tàfi] İkko [dà Bàlki]

Femi 3PL.PFV go Lagos with Balki

'Femi went to Lagos with Balki'. (p.188)

Normal Coord. b. [Feemì dà ùba-n-shì] sun tàfi İkko Femi with father-of-3SG.M 3PL.PFV go Lagos

'Femi and his father went to Lagos'. (p.183)

An important difference arises, however, when one compares these constructions in more depth. Both Passamaquoddy and Hausa have alternative normal coordination structures which result with a plural NP without changing the plural morphology on the verb. This is shown in (5b) and (6b), respectively. Otomi is different in this respect. In Otomi, the comitative NP is an argument of the verb which is always encoded in a split. This is shown in (7) which is an example with an obligatory elliptical reading that evinces that the construction in (1) has an obligatory split. Little pro stands here for a covert comitative NP whose reference is recoverable from context:

$$
\begin{array}{llllll}
{[\mathrm{no}=\mathrm{r}} & \text { Mária } & \text { 'ne }=\mathrm{r} & \text { Tóño] } & \text { mí= ñó }=\mathbf{w i} & \text { pro } \\
\text { DEF.SG=SG } & \text { Mary } & \text { and }=\mathrm{SG} & \text { Tony } & \text { 3.IMP=talk=DU } &
\end{array}
$$

a) 'Mary and Tony were talking with him'.

b) *'Mary and Tony were talking to each other'.

If the reading in (7b) is wanted, the construction in (8), which is not an instance of the SCC, must be used. Notice the absence of dual morphology on the verb:

$$
\begin{aligned}
& \text { [nǒ }=\mathrm{r} \quad \text { Mária } \quad \text { ně }=\mathrm{r} \text { Tóño }] \text { mí= ñó } \\
& \text { DEF.SG }=\text { SG Mary and }=\text { SG Tony 3.IMP }=\text { talk } \\
& \text { 'Mary and Tony were talking to each other'. }
\end{aligned}
$$

Otomi is a null-subject or pro-drop language. Topical subjects are most commonly not overtly expressed. As a consequence of this, the focal participants in most textual instances of the construction are elided NP subjects, as in (9a), which shows two instances of the construction. In contrast, the comitative NP functions as an antitopic; that is, it often bears new information, and because of this it is commonly overtly stated, as in (9a), were we have two explicit NPs. But once it is established in discourse, it may not be mentioned, as shown in (9b):

(9) a. ntónse pro bi $=$ n-thě $=$ wí $\quad[$ 'na $=\mathbf{r} \quad$ jö'í $]$

$$
\text { then } \quad \text { 3.PST }=\mathrm{M}-\mathrm{meet}=\mathrm{DU} \text { IND.SG}=\mathrm{SG} \text { person }
$$

$\varnothing$ pro $m^{\prime} 1=<\tilde{\mathrm{n}}>{ }^{\prime} \mathrm{o}=\mathrm{w}_{1}[=\mathbf{r} \quad$ t'intxú $]$

REL $\quad 3 . I M P=<$ NPS.M $>$ walk $=$ DU $(3 P O S S)=S$ daughter

'He then came across a man who was walking along with his daughter' 
(Hormigas: 2669)

b. ba $=$ ju $^{\mathrm{h}} \mathrm{k}-\varnothing-\mathrm{i} \quad$ sta $\mathrm{ká}=\mathrm{r} \quad$ nöní $=\mathrm{r}$ déhé 3.PST.SEQ $=$ get.sb.out-3OBJ-F up.to $\mathrm{LOC}(3 \mathrm{POSS})=\mathrm{SG}$ edge $=\mathrm{SG}$ water 'ně yá pro bi $=\tilde{\text { nó }}=\mathrm{w} 1=$ ' $\mathrm{ya}=$ 'na pro and $\mathrm{P} \quad$ 3.PST $=$ talk $=\mathrm{DU}=\mathrm{P}=\mathrm{QUOT}$

i. 'He got him out up to the edge of the water, and he talked to him'.

ii. *'He got him out up to the edge of the water, and they talked'.

(T\&B: 185-86)

As a direct consequence of this grammatical property, the SCC is often instantiated in natural discourse by the verbal predicate only, as in (9b). This makes it rather difficult to identify at first glance because the verb gives the false impression that it is a predicate with a dual NP subject, much in the fashion of the normal coordinating constructions in (5b) and (6b) in Passamaquoddy and Hausa. Under this false impression, (9b) would translate as (ii) when it really doesn't.

In this paper, I propose that the SCC in Otomi emerged as a specialized comitative construction when the number morphology involved in it underwent a heavy restructuring in other realms of the grammar, more particularly, as dual morphology became a nearly extinct inflectional category outside the construction.

\section{Plural and Dual in San Ildefonso Otomi}

Subject agreement in SI Otomi is encoded in the verb by means of complex paradigms of verbal proclitics which also encode tense/aspect/mood (TAM). A few such paradigms are shown in (10):

\begin{tabular}{|c|c|c|c|}
\hline (10) & $1^{\mathrm{st}} \mathrm{p}$. & $2^{\text {nd }} \mathrm{p}$. & $3^{\text {rd }} \mathrm{p}$ \\
\hline Present ( Habitual) & $d_{1}^{\prime}=$ & $g 1=$ & $\varnothing=$ \\
\hline Imperfect & $n-d_{1}^{\prime}=$ & $n-g_{1}^{\prime}=$ & $m^{\prime} 1=$ \\
\hline Past ( Completive) & dá $=$ & gá = & $\mathrm{bi}=$ \\
\hline Irrealis $(\sim$ Future $)$ & $\mathrm{ga}=$ & $\mathrm{gi}=$ & $\mathrm{da}=$ \\
\hline
\end{tabular}

Example (11a) below illustrates the use of the past tense proclitics dá and $b i$, encoding $1^{\text {st }}$ and $3^{\text {rd }}$ person subject, respectively. When only the proclitics in (10) are used, the grammatical number of the subject is interpreted as singular by default. If cross-reference of a non-singular subject is needed, number enclitics must be used as, for example, in (7):

$$
\begin{aligned}
& \text { a. yá nú dá ='óhö, yá 'ín-dá=pö̀-i té bi=jǎ } \\
& \text { P when 1.PST=sleep.F P NEG-1.PST=know.F-F what } 3 . P S T=\text { happen } \\
& \text { 'When I went to sleep, I didn't know what happened'. } \\
& \text { (Temblor: 753-54) }
\end{aligned}
$$




\section{Split Coordination in Otomi}
b. níxi gí =tsă- $\varnothing=\mathbf{h u ́}$
nor $2 . \mathrm{PRS}=$ sentir-3OBJ $=\mathrm{PL}$
'Nor you (PL) realize it'. (Dinero del Abuelo)

All number enclitics, including plural and dual number, are given in (12). I present here default allomorphs only. Shaded areas indicate absence of marking:

\begin{tabular}{|c|c|c|c|c|c|c|c|}
\hline (12) & & $1^{\mathrm{st}} \mathrm{p} . \quad 2^{\mathrm{nd}} \mathrm{p}$ & SUB & OBJ & $\begin{array}{l}\text { Verbs } \\
\text { tr. in. }\end{array}$ & Pronouns & Possessor \\
\hline P1. & Excl. & $\begin{array}{l}=h u^{\prime}=h u^{\prime} \\
=h e^{\prime}\end{array}$ & $\checkmark$ & $\checkmark$ & $\begin{array}{ll}\checkmark & \checkmark\end{array}$ & $\checkmark$ & $\checkmark$ \\
\hline Dual & Excl. & $\begin{array}{l}=\mathrm{w}^{\prime}=\mathrm{w} 1 \\
=\mathrm{be} \\
=\mathrm{b}^{\prime}\end{array}$ & $\checkmark$ & & $\checkmark$ & & \\
\hline
\end{tabular}

The distribution of the number enclitics in (12) may be compared with the one these enclitics have in the SCC, which is shown in (13):

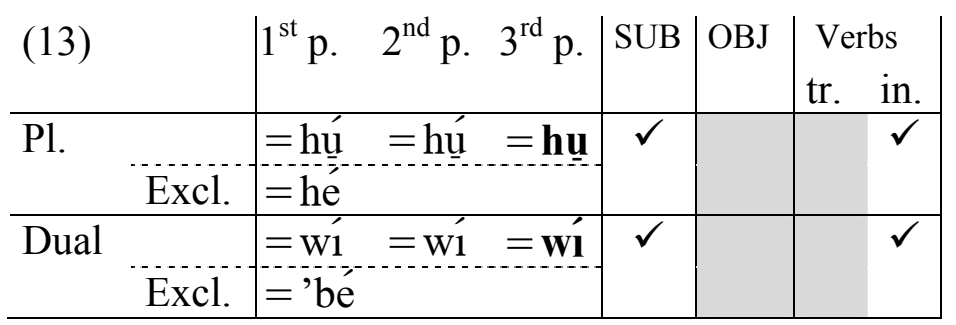

The first relevant difference between the functional distribution in (12) and (13) is that outside the SCC, number enclitics cannot be used for a $3^{\text {rd }}$ person subject, as indicated by the ungrammaticality of (14):

$$
\begin{aligned}
& * \mathrm{ma}=\mathbf{d a}=\mathrm{k} \text { 'öng- } \varnothing=\mathbf{w i ́} /=\mathbf{h u ́} \\
& \mathrm{PRG}=3 . \mathrm{IRR}=\text { go.and.see.S-3OBJ }=\mathrm{DU} /=\mathrm{PL} \\
& \text { Intended meaning: 'They will go and see it'. }
\end{aligned}
$$

With a $3^{\text {rd }}$ person, the interpretation of a singular or a plural subject is contextbounded, as shown in (15):

$$
\begin{aligned}
& \mathrm{ma}=\mathbf{d a}=\mathrm{k} \text { 'ön- } \varnothing-\mathrm{i} \\
& \mathrm{PRG}=3 . \mathrm{IRR}=\text { go.and.see-3OBJ-F } \\
& \text { 'He/she/they will go and see it'. }
\end{aligned}
$$

In contrast, inside the SCC, the marking of a non-singular $3^{\text {rd }}$ person is not only possible, but obligatory: 

a. pro

$$
\mathbf{b a}=\tilde{\mathrm{n}}-{ }^{\prime}{ }^{\prime}=\mathbf{w}^{\prime} / * \varnothing
$$$$
\left[\mathrm{nó}^{\prime}=\mathrm{r}\right.
$$
'béhñó]
3.PST.SEQ $=\mathrm{M}-\mathrm{walk}=\mathrm{DU} \quad$ DEF.SG.3POSS $=\mathrm{SG}$ woman

'He accompanied his wife'. (lit. 'He walked along with his wife'.)

(Celoso: 45)

$$
\begin{aligned}
& \text { b. pro } \left.\mathbf{d a}=\tilde{n}^{\prime} \text { éñ }=\mathbf{h u ́} / * \boldsymbol{\emptyset} \quad \text { [yá } \quad \text { ñǒhú }\right] \\
& \text { 3.IRR=play. } \mathrm{S}=\mathrm{PL} \quad \text { PL.3POSS friends } \\
& \text { 'He plays with his friends'. (Estela \& Ana.: 324) }
\end{aligned}
$$

As may be seen in (12), plural is a very productive inflectional category while dual is highly restricted: (a) dual cannot express the dual of an object; (b) it is not used with intransitive verbs; and (c) it is not found outside the realm of verbal morphology with pronouns or possessors.

Outside the SCC, plural is the default exponence of non-singular number. In other words, it indicates plural reference proper ("more than two"), as in (17a), as well as dual reference proper ("two"), as in (17b):

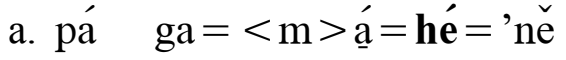
PURP $1 . I R R=<$ NPS $>$ go.PL $=1$ PL.EX $=$ too

Plural reference: 'So that we (ants) may also go'. (Hormigas: 2792)

$\begin{array}{lll}\text { b. }<\mathrm{m}>\underline{\mathrm{a}}=\text { 'mú, } & \text { ma } & \text { ga=tsi-thé= hé } \\ <\mathrm{NPS}>\text { go.1/2PL=let's } & \text { PRG } & 1 . \text { IRR=ingest-water.B=1PL.EX }\end{array}$

Dual reference: 'Let's go to have a drink'. (Moneda: 10)

(lit. 'let's go, so that we (you and I) will have a drink'.)

This picture inverts itself when we look inside the SCC, where dual is default and plural is restricted. For instance, plural can be used when the comitative NP refers to a multiplicity of individuals: not two, three or four, but many. In this sense, plural is an exponence of plural of abundance within the construction, as in (18), where the comitative NP refers to a football team:

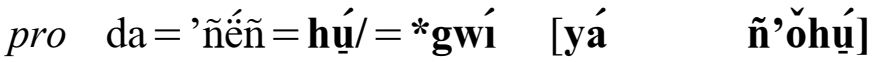

$$
\begin{aligned}
& \text { 3.IRR }=\text { play. } \mathrm{S}=\mathrm{PL} /=\mathrm{DU} \quad \text { PL.3POSS friends }
\end{aligned}
$$

In other cases inside the SCC, dual is used regardless of the number of participants involved. Example (19) illustrates this point:

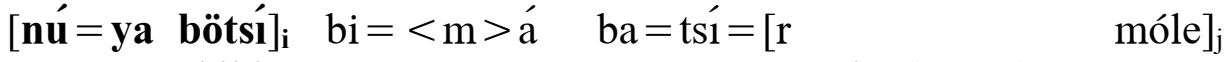

$$
\begin{aligned}
& \mathrm{DEF}=\mathrm{PL} \quad \text { child } 3 . \mathrm{PST}=<\mathrm{NPS}>\text { go 3.PST.SEQ }=\text { reach. } \mathrm{B}(3 \mathrm{POSS})=\mathrm{SG} \text { granny } \\
& \text { pá } \operatorname{pro}_{\mathbf{i}} \text { bi }=<\mathrm{m}>\text { ' } \underline{\underline{u}}=\mathbf{h w i} \quad \text { pro }_{\mathrm{j}} \\
& \text { PURP } \quad 3 . P S T=<\text { NPS.M }>\text { live. } S=D U
\end{aligned}
$$

'The (two) children went out to find their grandmother to live with her'. 


\section{Split Coordination in Otomi}

(Viejecita: 3-5)

In (19) the sum of the two children plus their grandmother equals three, but dual is still used. A similar case is shown in (20), where the comitative NP expresses a few individuals, not many; otherwise plural would be used as in (18). All this suggests that dual number on the verb expresses an asymmetric duality of two sets, rather than a duality of two entities:

$$
\begin{aligned}
& \text { kó yá pro } \varnothing=\mathrm{m} \text {-pö =hwí [nú=ya mạ́stro] } \\
& \text { because } \mathrm{P} \quad \text { 3.PRS }=\mathrm{M}-\mathrm{know} . \mathrm{S}=\mathrm{DU} \quad \mathrm{DEF}=\mathrm{PL} \text { master.builder } \\
& \text { 'Because he gets along with the master builders'. (J Miranda 2: 143) }
\end{aligned}
$$

\section{Other characteristics of the SCC}

In the previous section, I have shown a number of morphological features of the construction. The construction has other characteristics, for example, the verbs used in it. Transitive verbs are not allowed in the construction, as seen by the impossibility of (21):

$$
\begin{aligned}
& \text { *dá = tám- } \varnothing=\text { 'é } \quad \text { [nó ma 'indố] } \\
& \text { 1.PST=buy.S-3OBJ=1DU.EX DEF.SG 1POS S brother.of.woman } \\
& \text { Intended reading: 'I bought it with my brother'. }
\end{aligned}
$$

Table 1 in the Appendix represents a non-exhaustive list of the intransitive verbs used in the construction. The verbs in this table are organized according to whether they are morphologically basic or derived. At the top of the table, there are motion and activity verbs. Most of the verbs in the table are reciprocal verbs, and they have middle morphology. Such middle verbs may in turn be basic (deponent) or derived from other transitive verbs (see Palancar 2004 for more details). At the bottom of the table, I have included a number of intransitive verbs, derived from transitive verbs, which denote activities.

All the verbs in Table 1 are perceived as semantically agentive verbs. No inactive verb can occur in the construction, as shown, for example, in (22):

$$
\begin{aligned}
& \text { a. } * \text { bi }=<\mathbf{d}>\text { áng }=\text { wí }[=\mathrm{r} \quad \text { Pédro }] \\
& \text { 3.PST }=<\mathrm{NPS}>\text { fall.from.hight }=\mathrm{DU}=\mathrm{SG} \text { Peter } \\
& \text { Intended reading: 'He fell with Pedro (from a cliff)' } \\
& \text { b. }{ }^{*} \mathrm{bi}=<\mathbf{d}>\ddot{\mathbf{u}}=\text { wí }[=\mathrm{ma} \quad \text { 'indó }] \\
& \text { 3.PST }=<\mathrm{NPS}>\text { fall.from.hight }=\mathrm{DU}=1 \mathrm{POSS} \text { brother.of.woman } \\
& \text { Intended reading: 'He died together with my brother'. }
\end{aligned}
$$

The impossibility of using inactive verbs in the SCC suggests that the frame only allows verbs that semantically denote actions which can be performed by actors, 


\section{Enrique L. Palancar}

so that other co-actors can be involved. In other words, the construction is relegated to the expression of prototypical instances of comitative events.

Interestingly, the SCC in Passamaquoddy is likewise restricted to intransitive verbs, but in this language both agentive and non-agentive verbs are used. Compare (5a) with the use of the stative verb apolahsatpih 'be bald' in (23):

$$
\begin{aligned}
& \text { [Susehp] apolahsatpih-ik [Piyel-ol] } \\
& \text { Susehp be.bald-3PL Piyel-OBV } \\
& \text { 'Susehp and Piyel are bald'. }
\end{aligned}
$$

The fact that (23) is a well-formed structure reveals another important difference between Passamaquoddy and Otomi. The SCC in Passamaquoddy is a coordination structure which plays around the topicality of one of the conjuncts. In other words, it is not a dedicated comitative structure like the one in Otomi.

Otomi can encode a comitative participant by means of an oblique phrase with the preposition kó, a borrowing from Spanish con 'with'. Borrowing this alternative encoding proved convenient with verbs that weren't allowed in the native structure, such as transitive verbs and non-agentive intransitive verbs:
a. dá = tá- $\varnothing-\mathrm{i}$
[kó nó
ma 'indó]
1.PST=buy-3OBJ-F with DEF.SG 1POSS brother.of.woman
'I bought it with my brother'.
b. nú mí $=<\mathrm{z}>$ óho $\quad[\mathbf{k o ́}$ nǒ $=\mathrm{r}$ xíta Mǎmpü]
DEF 3.IMP $=<\mathrm{NPS}>$ arrive.here.F with DEF.SG $=\mathrm{SG}$ man Scraggy
'He arrived with the man named Scraggy'. (Largirucho)

Although they commonly prefer the SCC, with the verbs in Table 1 speakers may also use the oblique encoding in (24) as an alternative expression of the comitative participant. An example is given in (25) of both encodings: ${ }^{3}$

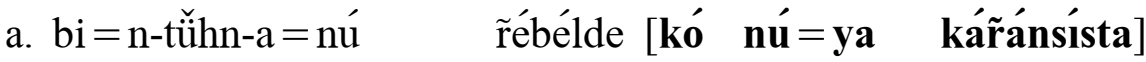 3.PST $=\mathrm{M}$-fight- $\mathrm{B}=\mathrm{DEF}(\mathrm{PL})$ rebel with $\mathrm{DEF}=\mathrm{PL}$ Carranza's.follower 'The rebels fought with Carranza's followers'. (Revolución 2)
b. nú rébélde bi=n-túm-kwí [nú=ya káránsísta] DEF(.PL)rebel 3.PST=M-fight.S=DU DEF=PL Carranza's.follower 'The rebels fought with Carranza's followers'.

\footnotetext{
3 I ignore whether there is a semantic contrast between these examples.

Dual is used in (25b) because the two armies are conceptualized as two wholes, rather than constituted of a multiplicity of individuals.
} 


\section{Split Coordination in Otomi}

\subsection{The two NPs in the SCC}

Topical subjects in SI Otomi precede the verb. Non-topical subjects of intransitive verbs may follow the verb as VS as in (25a). This word order possibility contrasts with the one found in the SCC. When the topical NP is overtly expressed, it must always precede the verb, suggesting that the construction has an obligatory topical subject slot that must be filled. With this in mind, compare example (25b) with the ungrammaticality of (26):

$$
\begin{array}{llll}
\text { *bi }=\text { n-tüm-kwí } \quad \text { [nú } & \text { rébélde] } & \text { nú=ya } & \text { kááánsísta } \\
\text { 3.PST=M-fight.S=DU DEF(.PL) } & \text { rebel } & \text { DEF=PL } & \text { Carranza's.follower } \\
\text { Intended reading: 'The rebels fought with Carranza's followers'. }
\end{array}
$$

In the neutral word order, the comitative NP in the SCC is placed after the verb. SI Otomi being an SVO language, this NP behaves like a regular complement in this respect. For instance, adjuncts cannot occur between the verb and its complements, as shown in (27a) and supported by the impossibility of (27b), where the adjunct M'óndá occurs between the verb and the complement NP:
a. há'bú gi=pěewí [ma nồnö] M'óndá
where 2.IRR $=\mathrm{go} . \mathrm{DU}=\mathrm{DU} 1 \mathrm{POSS}$ mother México
'Where you go with my mother to Mexico'. (Estela \& Ana.: 407)
b. *há'bú gi =pě=wí M'óndá [ma nốnö] where 2.IRR=go.DU=DU México 1POSS mother Intended reading: 'Where you go to Mexico with my mother'.

The comitative NP is, nonetheless, a fully independent constituent, which can be questioned, as in (28a) or relativized, as in (28b):

$$
\begin{aligned}
& \text { a. [tó } \quad \text { gi }=\text { 'bú=hwí } \quad t \text { hí } \\
& \text { who 2.IRR=live.S=DU } \\
& \text { 'With whom would you live } t \text { ?'. (Conversa Estela: } 3 \text { ) }
\end{aligned}
$$
b. ánke $\varnothing=$ 'bú-i $\quad[$ tó ga $=<\mathrm{m}>$ ě $=$ 'bé $t$
although 3.PRS $=$ be-F who $1 . \mathrm{IRR}=<\mathrm{NPS}>$ go.DU $=1$ DU.EX
[gó $\quad \mathrm{da}=$ mồn $=$ 'á⿴]

REL.CLEFT(3) 3.IRR=talk.S $=3 \mathrm{SG}$

'Although there's somebody I'd go with $t$ who may talk in my favor'. (Estela \& Ana.: 495)

\section{The emergence of the SCC}

In the previous sections we have seen a number of important characteristics of the SCC construction: (a) it has an obligatory split; (b) the topical position of the NP encoding the focal participant is obligatory; and (c) the number morphology in the 
construction has a particular distribution. These characteristics serve to define this coordination construction in Otomi as a specialized structure dedicated to the expression of a comitative event.

In this section, I advance a possible account for the way this construction may have emerged in SI Otomi. All Otomi languages have a construction similar to the one in SI Otomi, e.g. it may be seen in Sierra Otomi (Voigtlander and Echegoyen 1985); in Santiago Mexquititlán Otomi (Hekking 1995); etc. Nevertheless, as the construction has not been properly identified yet, it remains to be seen to what extent the similarities apply. Old Otomi had a flexible VOS word order. This may be seen, for instance, in some elicited examples in Cárceres (1580/1907) and in textual examples from the Huichapan Codex of the XVI ${ }^{\text {th }}$ century (Ecker 2001). This VOS order is still present in conservative dialects like Sierra Otomi (Voigtlander and Echegoyen 1985), but S may fluctuate in a topical preverbal position. From a normal coordinating structure like the one schematized in (28a) with a normal VS word order, the language developed a coordinating construction with a split, sketched in (28b). This happened by virtue of placing the one NP in the conjoined structure that was more topical in a preverbal position:
Normal Coordination
Split Coordination
a. $\mathrm{V}=\mathbf{D U}\left[\mathrm{NP}_{1}\right.$ (and) $\left.\mathrm{NP}_{2}\right]>$ b. $\left[\mathbf{N P}_{\mathbf{1}}\right]_{\text {Tор }} \mathrm{V}=\mathbf{D U}\left[\mathrm{NP}_{2}\right]$

At this stage, the emergent structure in (28b) may have been similar to the one found in Passamaquoddy, as described in Bruening (2004). In other words, it was a coordinating structure that played around the topicality of one of the conjuncts. This emergent construction served well as a conveyer of the semantics of a comitative event because it profiled one actor and placed the other co-actor in the background. As such, it later became frozen as a dedicated comitative structure in SI Otomi when both the split and the topical preverbal position of the focal participant became obligatory.

The SCC emerged as a structural island in the grammar of SI Otomi as dual morphology became less productive elsewhere in the system. Dual is a very productive inflectional category in other Otomi languages, especially in the ones spoken in The State of Mexico. For example, in Toluca Otomi (Lastra 1989, 1992), dual has the same functional productivity as plural in SI Otomi. In this respect, Toluca Otomi should be seen as a conservative language preserving the number morphology of historical Otomi. This original number system, extracted and adapted from Cárceres (1580/1907), is given in (29):

\begin{tabular}{|c|c|c|c|c|c|c|c|}
\hline (29) & & $1^{\mathrm{st}}$ p. $\quad 2^{\text {nd }}$ p. $\quad 3^{\text {rd }}$ p. & SUB & OBJ & \begin{tabular}{l}
\multicolumn{2}{|c}{ Verbs } \\
tr. in.
\end{tabular} & Pronouns & Possessor \\
\hline Pl. & Excl. & $\begin{array}{l}=h u^{\prime}=h u^{\prime}=h \underline{u} \\
=\text { hé }\end{array}$ & $\checkmark$ & $\checkmark$ & $\checkmark \checkmark \checkmark$ & $\checkmark$ & $\checkmark$ \\
\hline Dual & Excl. & $\begin{array}{l}=\mathrm{w} 1=\mathrm{w} 1=\mathrm{w} 1 \\
=\mathrm{wbe}^{\prime}\end{array}$ & $\checkmark$ & $\checkmark$ & $\begin{array}{ll}\checkmark & \checkmark\end{array}$ & $\checkmark$ & $\checkmark$ \\
\hline
\end{tabular}




\section{Split Coordination in Otomi}

In SI Otomi, as in other dialects such as Sierra Otomi (Voigtlander and Echegoyen 1985) and Mezquital Otomi (Hess 1968) the marking of number was lost in the $3^{\text {rd }}$ person, as was seen in (12). However, SI Otomi inherited the morphology involved in the original split coordination in (28b) and kept it intact, as was seen in (13), while number morphology underwent restructuring in other realms. When used in the frame, the markers involved, confined to the space of the construction, kept what was probably their original meaning in Otomi: dual marking expressing a duality of two sets regardless of the individuals involved, and plural marking expressing a plurality of abundance. Outside the space of the construction, number morphology was further reanalyzed as an exponence of grammatical number per se. Most crucially, the use of dual number became almost extinct in the grammar outside the frame, being mainly confined to transitive verbs and thus allowing plural morphology to become the default exponence of non-singular number in SI Otomi; a process which also occurred in Mezquital Otomi. The opposite process occurred in the isolated dialect of Ixtenco Otomi (Lastra 1997), where the old dual morphology was reanalyzed as default exponence of non-singular number.

\section{References}

Abdoulaye, Mahamane L. 2004. Comitative, coordinating, and inclusory constructions in Hausa, in Martin Haspelmath (ed.) 2004, 165-196.

Bruening, Benjamin. 2004. Split Coordination in Passamaquoddy, MS.

Cárceres, Fray Pedro de. 1580/1907. Arte de la lengua otomí. Published by Nicolás León, Boletín del Instituto Bibliográfico Mexicano VI.

Ecker, Lawrence. 2001. Códice de Huichapan: peleografía y traducción. Edited by Yolanda Lastra and Doris Bartholomew. Universidad Nacional Autónoma de México.

Hekking, Ewald. 1995. El otomí de Santiago Mexquititlán: Desplazamiento lingüístico, préstamos y cambios gramaticales. Studies in Language and Language Use, no. 17. Amsterdam: Institute for Functional Research into Language and Language Use.

Hess, H. Harwood. 1968. The Syntactic Structure of Mezquital Otomi. (Janua Linguarum. Series Practica, no. 43). The Hague: Mouton.

Lastra, Yolanda. 1992. El otomí de Toluca. Mexico DF: Instituto de Investigaciones Antropológicas, Universidad Autónoma Nacional de México.

Lastra, Yolanda. 1997. El otomí de Ixtenco. Mexico DF: Instituto de Investigaciones Antropológicas, Universidad Autónoma Nacional de México.

Stolz, Thomas. 2001. On Circum-Baltic instrumentals and comitatives, in Östen Dahl and Maria Koptjevskaja-Tamm (eds.), Circum-Baltic languages. Volume 2: Grammar and typology. Amsterdam/Philadelphia: John Benjamins. 591612. 


\section{Enrique L. Palancar}

Voigtlander, Katherine and Echegoyen, Artemisa. 1985. Luces contemporáneas del otomí: Gramática del otomí de la sierra. México, D.F. Instituto Lingüístico de Verano. [First impression in 1979 without author names].

Zavala, Roberto. (to appear). Inversion and obviation in Mesoamerica. Linguistische Berichte, Sonderheft 14. Helmut Buske Verlag.

\section{Appendix}

\begin{tabular}{|c|c|c|}
\hline \multicolumn{3}{|l|}{ Table 1 Verbs in the SCC } \\
\hline BASIC & & \\
\hline \multicolumn{3}{|l|}{ Unmarked: } \\
\hline$p \check{e}=D U$ 'go with sb.' & pá 'go' & \\
\hline '产=DU 'come with sb.' & 'éhë ‘come' & \\
\hline ñung $=D U$ 'have a meal with sb.' & ñúni 'have a meal' & \\
\hline 'bú $=D U$ 'live with sb.' & 'búi 'live' & \\
\hline$\tilde{n} \tilde{o}=D U$ 'talk with sb.' & $\tilde{n} \tilde{O}$ 'talk’ & \\
\hline \multicolumn{3}{|l|}{ Middle: } \\
\hline$\tilde{n}-{ }^{\prime}=D U$ 'go with sb./accompany sb.' & 'yó 'walk, go about' & \\
\hline \multicolumn{3}{|l|}{ Reciprocal: } \\
\hline \multicolumn{3}{|l|}{$n-k \ddot{u}=D U$ 'chase sb.' } \\
\hline \multicolumn{3}{|l|}{$n-t e^{\prime}=D U$ 'get close to sb./harass sb.' } \\
\hline$n$-there $=D U$ 'meet with sb.' & n-the 'meet' & \\
\hline \multicolumn{3}{|c|}{$n$-ts $\underline{a}=D U$ 'fight with sb./be busy with sth.' $n$-ts $\tilde{\underline{a}}^{2}$ 'fight' } \\
\hline$n$-tǘm $=D U$ 'quarrel with sb.' & $n$-tühni 'quarrel' & \\
\hline$n$-tsot $=D U$ 'lean against sb./sth.’ & $n$-tsote $e^{3}$ 'lean against e.o.' & \\
\hline$\tilde{n}$-hóga-mui=DU 'reconcile with sb.' & $\tilde{n}$-hóga-mui 'reconcile' & \\
\hline$n$-thex $x$ - ${ }^{\prime}=D U$ 'friendly get along with sb.' & n-thex-jí 'like e.o.' & \\
\hline \multicolumn{3}{|c|}{ DERIVED } \\
\hline \multicolumn{3}{|l|}{ Reciprocal: } \\
\hline$\tilde{n}-h \underline{u}=D U$ 'hug with sb.' & $\tilde{n}$-hǔfi 'hug e.o.’ & $h \underline{u} f i$ 'hug' \\
\hline n-tóts $=D U$ 'bump/trip with sb./sth.' & n-tóts'e 'bump against e.o.' & tóts'e 'stop', \\
\hline n-thöt $=D U$ 'marry with sb.' & n-thöti 'marry' & thöti 'answer' \\
\hline$m-f_{\underline{a}}^{2} x=D U$ 'help (with) sb.' & $m$-făts' $i$ 'help e.o.' & fáts' $i$ 'help' \\
\hline$\tilde{n}-h \bar{e}=D U$ 'separate from sb.' & $\tilde{n}$-hége 'separate' & hége 'split' \\
\hline$n$-zéngwa $=D U$ 'greet with sb.' & n-zéngwa' 'greet' & zéngwa 'greet' \\
\hline m-pont $=D U$ 'get across with sb.' & m-pont' $i$ 'get across e.o.' & pont'i 'cross' \\
\hline$m-p \check{o}=D U$ 'get along with sb.' & & pödi 'know' \\
\hline$n$-tsix $=D U$ 'get along with sb.' & & tsits' $i$ 'lead' \\
\hline$m \underline{a}=D U$ 'appreciate sb.' & & madi 'love' \\
\hline \multicolumn{3}{|l|}{ Activities: } \\
\hline$m-p \underset{\underline{e}}{e}=D U^{\prime}$ 'work together with/for sb.' & m-pefi ‘work' & pefi 'work at sth. \\
\hline $\begin{array}{c}n \text {-tám }=D U \text { 'shop together with sb.' } \\
\quad \text { (in the same stalls) }\end{array}$ & n-tái 'shop in the market' & tái 'buy’ \\
\hline $\begin{array}{r}m-p \underline{a}=D U \text { 'sell together with sb.' } \\
\text { (to the same customer) }\end{array}$ & $m$-pă 'go selling' & $p \underline{a}$ 'sell' \\
\hline$n-z i=D U$ 'have a drink with sb.' & & tsi 'ingest' \\
\hline
\end{tabular}

Abbreviations in Table 1: e.o 'each other'; $s b$. 'somebody'; sth. 'something' 